\title{
A PELAGIC MARINE DIATOM REQUIRING COBALAMIN
}

\author{
By M. R. Droop \\ The Marine Station, Millport
}

A bacteria-free culture of the important centric diatom Skeletonema costatum has recently been established at Millport, and some exploratory nutritional experiments have been carried out with it. S. costatum is a photo-autotroph whose autotrophy is, apparently, limited to cobalamin (vitamin $\mathrm{B}_{12}$ ).

Details concerning isolation and maintenance of $S$. costatum differ from those already published (Droop, 1954 $a$, 1955) only in the matter of $\mathrm{pH}$ control, a vital factor in the successful culture of this species whose range of tolerance is narrow $(\mathrm{pH} 7 \cdot 5-8 \cdot 5)$.

A synthetic solution $\left(S_{36}\right)$ was developed for and used in the experiments to be described:

\begin{tabular}{|c|c|c|c|}
\hline & $S_{36}$ & & \\
\hline $\begin{array}{l}\mathrm{KNO}_{3} \\
\mathrm{~K}_{0} \mathrm{HPO}_{4}\end{array}$ & $100 \mathrm{mg}$ & 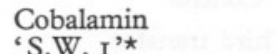 & $\begin{array}{l}100 \mathrm{~m} \mu \mathrm{g} \\
250 \mathrm{ml} .\end{array}$ \\
\hline $\begin{array}{l}\mathrm{K}_{2} \mathrm{H}_{2} \mathrm{NiO}_{3} \\
\mathrm{Na}_{2}\end{array} \mathrm{H}_{2} \mathrm{O}$ & $\begin{array}{l}10 \mathrm{mg} \\
\text { I0O } \mathrm{mg}\end{array}$ & 'S.W. 2 , & $\begin{array}{r}250 \mathrm{ml} . \\
5 \mathrm{ml} .\end{array}$ \\
\hline Tris-(hydroxymethyl)-aminomethane & $500 \mathrm{mg}$ & 'T.M. 2'^ & Io $\mathrm{ml}$. \\
\hline Thiamin & I $\mathrm{mg}$ & Glass distilled water & $735 \mathrm{ml}$. \\
\hline
\end{tabular}

S. costatum has been carried through more than ten transfers in this medium and growth has been as good as in any containing soil and liver extracts and natural sea water. The medium was adjusted to $\mathrm{pH} 8 \cdot \mathrm{I}$ before being decanted into test-tubes and autoclaved for a few moments at $15 \mathrm{lb}$., inoculations being carried out $\mathrm{I} 8 \mathrm{hr}$ later from exponentially growing cultures.

The sensitivity of $S$. costatum to $\mathrm{pH}$ was such as to require the use of replications in all vitamin experiments. This rendered conventional doseresponse layouts very unwieldy. Consequently, the requirement for cobalamin was demonstrated qualitatively by the use of a serial transfer technique in which cultures receiving a full dose of the vitamin were compared with those receiving none. At each stage inoculations were taken from a vitamin-free culture of the previous stage to one batch of medium containing the vitamin and to one vitamin-free, the two batches having been prepared and adjusted as one, then divided for the addition of the vitamin, and autoclaved simultaneously.

The results of these experiments are shown in Table I. The magnitude of the errors occasioned by the difficulty of adequately controlling $\mathrm{pH}$ is not sufficient to obscure the fact that significantly poorer yields were obtained in the vitamin-free controls in each trial after the first. Inocula for the latter

* For composition of these metal solutions, see Droop (1955). 
were from stock, hence carry-over of cobalamin in this instance would not be negligible. The results show that cyanocobalamin, the vitamin proper, can be spared by the variants, pseudo-vitamin $\mathrm{B}_{12}$, factor $\mathrm{A}$ and factor $\mathrm{B}$; but the experiments were not such as to be able to determine the relative activities of these variants, nor indeed to determine whether the requirement for cobala$\mathrm{min}$ is absolute.

Table I. Effect of Cobalamin at a Concentration of ioo $\mathrm{m} \mu \mathrm{g} / \mathrm{l}$. on Growth of Skeletonema costatum on SERIAL TRANSFER IN MEDIUM

\section{$S 36$ LESS CoBALAMIN}

Inocula were taken from controls of previous transfer (dilution factor: 100). Final yields measured optically (per cent absorption).

$\begin{array}{lccc}\text { First transfer } & \begin{array}{c}\text { Mean } \\ \text { percentage } \\ \text { absorption }\end{array} & \begin{array}{c}\text { Standard } \\ \text { error }\end{array} & \text { Replications } \\ \text { With cyanocobalamin } & \text { I7 } & \text { I.6 } & 5 \\ \text { Control } & \text { I6 } & 0 \cdot 8 \mathrm{I} & 5 \\ \text { Second transfer } & & & \\ \text { With cyanocobalamin } & 26 & \mathrm{I} \cdot \mathrm{I} & 5 \\ \text { Control } & 7 & 0 \cdot 84 & 5 \\ \text { Third transfer } & & & \\ \text { With cyanocobalamin } & \mathrm{I} 5 & 3 \cdot 8 & 7 \\ \text { With factor A } & \mathrm{I3} & 2 \cdot 2 & 7 \\ \text { With factor B } & \mathrm{IO} & 2 \cdot 2 & 7 \\ \text { With pseudo-B }{ }_{12} & 8 & 5 \cdot 0 & 7 \\ \text { Control } & 2 & 0 \cdot 62 & 7 \\ \text { Fourth transfer } & & & \\ \text { With cyanocobalamin } & 39 & 7 \cdot 5 & 7 \\ \text { With factor A } & 44 & 4 \cdot 6 & 7 \\ \text { With factor B } & 33 & 9 \cdot 0 & 7 \\ \text { With pseudo-B }{ }_{12} & 37 & 5 \cdot 9 & 7 \\ \text { Control } & 7 & \mathrm{I} \cdot 9 & 7\end{array}$

S. costatum resembles Bacterium coli in being able to utilize factor B as the sole source of the vitamin, factor B being that part of the molecule, common to the various forms, which remains after removal of the respective nucleotides (Ford \& Porter, I952). The requirement for cobalamin in this instance, therefore, is likely to be occasioned by a synthetic disability concerning this nonnucleotide portion, as in the case of B. coli (Ford, Holdsworth \& Kon, 1955). It cannot, however, yet be concluded that $S$. costatum is autotrophic with respect to the nucleotide, because the experiments were undertaken with a culture medium containing thiamin; but this may be the case.

A similar series of experiments with thiamin (in the presence of cobalamin) failed to demonstrate a significant requirement for this vitamin, but the use of cotton-wool plugs may account for this.

The culture of $S$. costatum in a state of bacteriological purity has allowed the first insight into the nutritional requirements of an important pelagic 
organism. It also provides a measure of hope that success will attend efforts to culture other pelagic species so necessary to an understanding of the biochemical ecology of the sea. Indeed, the concept of non-predatory relationships, though more than fifty years old (cf. Lucas, 1938), has, for want of proper experimental material, yet received no detailed support in the field of phytoplankton studies. The need for accessory substances for growth of marine diatoms, first postulated by Allen (I9I4) and later by Harvey (I939) and others, is paralleled by nutritional deficiencies in investigated euryhaline diatoms and flagellates (Hutner \& Provasoli, I953; Provasoli \& Pintner, I953; Lewin, I954; Droop, I954b; Sweeney, I954). Latterly, each investigation has tended to make more probable the general importance of cobalamins in the economy of the sea, though the species investigated have mostly been supralittoral or estuarine. The requirement in S. costatum is, therefore, of interest, and it is noteworthy that in this species, which possibly resembles other pelagic diatoms, there is a lack of specificity in the form of the vitamin preferred.

Grateful acknowledgement is made to Dr L. Provasoli (Haskins Laboratories, New York) for an introduction to the useful $\mathrm{pH}$ buffer, tris-(hydroxymethyl)-aminomethane, and to Dr J. E. Ford (N.I.R.D., Shinfield) for samples of factors $\mathrm{A}$ and $\mathrm{B}$ and pseudo-vitamin $\mathrm{B}_{12}$.

\section{REFERENCES}

AlleN, E. J., I9I4. On the cultures of the plankton diatom Thalassiosira gravida Cleve in artificial sea water. F. Mar. biol. Ass. U.K., Vol. Io, pp. 417-39.

Droop, M. R., I954a. A note on the isolation of small marine algae and flagellates for pure cultures. F. Mar. biol. Ass. U.K., Vol. 33, pp. 5II-I4.

- 1954b. Cobalamin requirement in Chrysophyceae. Nature, Lond., Vol. 174, p. 520.

_ 1955. Some new supra-littoral Protista. F. Mar. biol. Ass. U.K., Vol. 34, pp. $233-45$.

Ford, J. E., Holdsworth, E. S. \& Kon, S. K., 1955. The biosynthesis of vitamin $\mathrm{B}_{12}$-like compounds. Biochem. F., Vol. 59, pp. 86-92.

Ford, J. E. \& PORTER, J. W. G., I952. Some properties of vitamin $B_{12}$-like factors from calf faeces. I. Characteristics of different fractions. Biochem. F., Vol. $5 \mathrm{I}$, v.

Harvey, H. W., 1939. Substances controlling the growth of a diatom. F. Mar. biol. Ass. U.K., Vol. 23, pp. 499-519.

HutneR, S. H. \& Provasol, L., I953. A pigmented marine diatom requiring vitamin $\mathrm{B}_{12}$. News Bull. Phycol. Soc. Amer., Vol. 6, No. I8.

LEwIN, R. A., I954. A marine Stichococcus sp. which requires vitamin $\mathrm{B}_{12}$ (cobalamin). F. gen. Microbiol., Vol. I0, pp. 93-6.

LUCAS, C. E., 1938. Some aspects of integration of plankton communities. F. Cons. int. Explor. Mer, Vol. 13, pp. 309-22.

Provasoli, L. \& PINTNER, IRMA J., I953. Ecological implications of in vitro nutritional requirements of algal flagellates. Ann. N.Y. Acad. Sci., Vol. 56, pp. 839-5r.

SWEENEY, BEATRICE M., I954. Gymnodinium splendens, a marine dinoflagellate requiring vitamin $\mathrm{B}_{12}$. Amer. F. Bot., Vol. 4I, pp. 82I-24. 